Check for updates

Cite this: RSC Adv., 2018, 8, 16400

Received 8th February 2018

Accepted 21st April 2018

DOI: $10.1039 / c 8 \mathrm{ra01217b}$

rsc.li/rsc-advances

\section{Biocatalysis of ursolic acid by the fungus Gliocladium roseum CGMCC 3.3657 and resulting anti-HCV activity $\dagger$}

\author{
Shaobin Fu, iD *ab Qingfeng Meng, ${ }^{c}$ Junshan Yang, ${ }^{a}$ Jiajia Tu ${ }^{b}$ and Di-An Sun*a \\ Biocatalysis of ursolic acid (UA 1) by Gliocladium roseum CGMCC 3.3657 was investigated. Baeyer-Villiger \\ oxidation was found to occur during the reaction. Four metabolites were isolated from the cultures and \\ their structures were identified as 21-oxo,A-homo-3a-oxa-urs-12-en-3-one-28-oic acid (2), 21-oxo- \\ 3,4-seco-ursan-4(23),12-dien-3,28-dioic acid (3), 21ß-hydroxyl-A-homo-3a-oxa-urs-12-en-3-one-28- \\ oic acid (4) and 21ß-hydroxyl-3,4-seco-ursan-4(23),12-dien-3,28-dioic acid (5), based on their NMR and \\ MS spectral data. All of the four metabolites were new and their anti-HCV activity was tested. Their \\ biotransformation pathway was also proposed.
}

\section{Introduction}

Ursolic acid (UA) is a pentacyclic triterpene acid capable of inhibiting various types of cancer cell. It was reported that UA inhibited several human breast cancer cell lines by activating caspase 3 and poly(ADP-ribose) polymerase cleavage, and this resulted in apoptosis. ${ }^{1}$ It can inhibit the cell proliferation of the human lung cancer cell line A549 by blocking cell cycle progression in the $\mathrm{G} 1$ phase which decreases the protein expression. ${ }^{2}$ Protein tyrosine phosphatase 1B (PTP1B) is a key element in the negative regulation of the insulin signalling pathway and may play an important role in diabetes and obesity. $^{3}$ UA can induce apoptosis by activating p53 and caspase-3 gene expression and suppressing the NF- $\kappa \mathrm{B}$ mediated activation of bcl-2 to inhibit B16F-10 melanoma cells. ${ }^{2}$ UA has also demonstrated antibacterial activity against strains Enterococcus faecalis and Staphylococcus aureus, ${ }^{4}$ and has an antiarthritic, ${ }^{5}$ anxiolytic-like ${ }^{6}$ and hepatoprotective effect. ${ }^{7}$ Furthermore, UA exhibits potential anti-diabetic ${ }^{8}$ and obesity prevention effects. ${ }^{9}$

Structural modification of UA was carried out to improve its solubility and biological activity. ${ }^{\mathbf{1 0 - 1 2}}$ Since UA does not have a lot of active sites for traditional organic modification, biocatalysis was investigated as a very good method to modify UA to obtain new metabolites. ${ }^{13-15}$

\footnotetext{
${ }^{a}$ Institute of Medical Plant Development, Chinese Academy of Medical Sciences, Peking Union Medical College, Beijing 100193, China.E-mail: diansun@sina.com; fushb@ 126.com; Fax: +86-0851-28609493; Tel: +86-10-57833298; +86-0851-28642513

${ }^{b}$ Pharmacy School of Zunyi Medical University, Zunyi 563000, China ${ }^{c}$ Department of Public Health, Zunyi Medical University, Zunyi 563000, China

$\dagger$ Electronic supplementary information (ESI) available. See DOI: 10.1039/c8ra01217b
}

The hepatitis $\mathrm{C}$ virus (HCV) infects 170 million people around the world and is mostly transmitted via parenteral routes. The increased risk of HCV development in HCV-infected patients arises from the development of liver fibrosis and cirrhosis as a result of chronic inflammation. ${ }^{16}$ HCV entry inhibitors could satisfy a tandem mechanism for use with other inhibitors of viral replication, ultimately leading to a multifaceted approach for the eradication of the HCV infection. Recently, the inhibitory activity on HCV entry of EA and a series of derivatives was investigated, and EA and some of the derivatives showed potency for anti-HCV entry activity. ${ }^{17-19}$

This paper reports the microbial transformation of UA and also pentacyclic triterpene acid by filamentous fungus $G$. roseum CGMCC 3.3657. Hydroxyl and ketone groups were introduced in a regio- and stereo-selective way at C-21 which is difficult for organic synthesis. We suggest that ring A may be catalyzed by Baeyer-Villiger (BV) enzymes to form a seven-membered ring lactone and thus ring A can be cleaved. Compounds 2 and 3 exhibited better anti-HCV activity than 1, 4 and 5. This result indicates that the ketone group at C-21 may help to block HCV entry. Furthermore, the biotransformation pathway was also proposed.

\section{Results and discussion}

\section{Identification of the products}

UA was incubated with the fungus G. roseum CGMCC 3.3657. Four transformation products were afforded (Fig. 1).

Metabolite 2 was more polar than the substrate. The HR-ESIMS data $\left([\mathrm{M}-\mathrm{H}]^{-}:\right.$483.3104) of 2 (Appendix 2-1†) suggested a molecular formula of $\mathrm{C}_{30} \mathrm{H}_{44} \mathrm{O}_{5}$. There were two more oxygen atoms than the substrate (1). The ${ }^{1} \mathrm{H}-\mathrm{NMR}$ spectrum (Appendix 2-2 and 2-3†) revealed the presence of seven methyl groups, five with a singlet and two with a double peak. The signal at $\delta_{\mathrm{H}} 3.46$ 


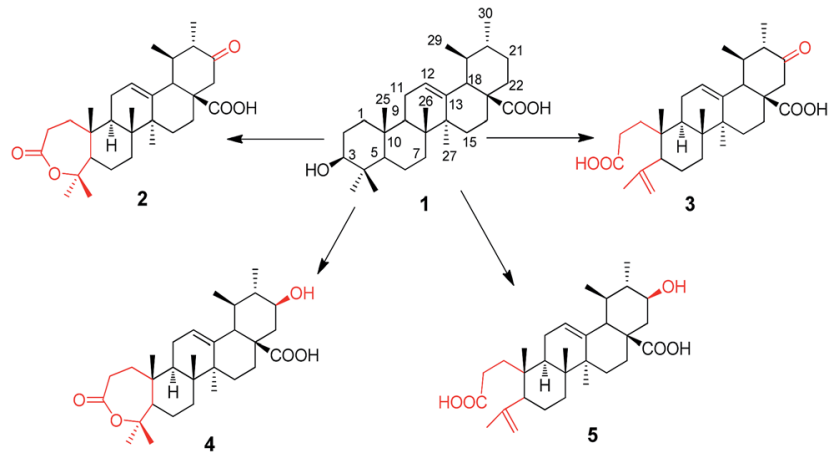

Fig. 1 Microbial transformation of UA by G. roseum CGMCC 3.3657.

assigned to $\mathrm{H}-3 \alpha$ in the substrate disappeared in product 2 . The carbon signals (Appendix $2-4 \dagger$ ) changed significantly, indicating the presence of two carboxyl groups $\left(\delta_{\mathrm{C}} 174.2\right.$ and $\delta_{\mathrm{C}}$ 175.7). Analysis of the HMBC data (Fig. 2) revealed that the carbonyl group $\left(\delta_{\mathrm{C}} 209.5\right)$ was at $\mathrm{C}-21$ based on the correlation between $\mathrm{C}-21$ and $\mathrm{H}-22\left(\delta_{\mathrm{H}} 2.65\right.$ and $\left.\delta_{\mathrm{H}} 2.39\right)$ and the correlation between $\mathrm{C}-21$ and $\mathrm{H}-30\left(\delta_{\mathrm{H}} 0.93, \mathrm{~d}\right.$ and $\left.J=6.6 \mathrm{~Hz}\right)$. The carboxyl group $\delta_{\mathrm{C}} 174.2$ was assigned to $\mathrm{C}-28$ based on the HMBC data (Fig. 2) due to the correlation between C-28 and $\mathrm{H}-22$. The signal at $\delta_{\mathrm{C}} 85.4$, correlated with both $\mathrm{H}-23\left(\delta_{\mathrm{H}} 1.38\right)$ and $\mathrm{H}-24\left(\delta_{\mathrm{H}} 1.33\right)$ in the HMBC spectrum (Fig. 2), may be attributed to C-3 or C-4 (Appendix 2-6 and 2-7†). This was further identified as C-4 and the signal at $\delta_{\mathrm{C}} 175.4$ was confirmed to be $\mathrm{C}-3$ with reference to the data of a known compound (A-homo-3a-oxa-olean-12-en-3one-28-oic acid), ${ }^{20}$ which is structurally similar to product 2 . Based on the above evidence, product 2 was elucidated as 21oxo,A-homo-3a-oxa-urs-12-en-3-one-28-oic acid.

Metabolite 3 showed an $[\mathrm{M}-\mathrm{H}]^{-} \mathrm{m} / \mathrm{z}$ peak at 483.3105 on the HR-ESI-MS spectrum (Appendix 3-1†), corresponding to the molecular formula of $\mathrm{C}_{30} \mathrm{H}_{44} \mathrm{O}_{5}$. In the ${ }^{1} \mathrm{H}-\mathrm{NMR}$ spectrum (Appendix 3-2 $\dagger$ ), two more olefinic proton signals at $\delta_{\mathrm{H}} 4.65$ and $\delta_{\mathrm{H}} 4.86$ with respective singlet peaks appeared besides $\mathrm{H}-12$ at $\delta_{\mathrm{H}} 5.40(\mathrm{t}, J=3.6 \mathrm{~Hz})$, and only six methyl group signals were observed. Correspondingly, the ${ }^{13} \mathrm{C}-\mathrm{NMR}$ spectrum (Appendix 3$3 \uparrow)$ revealed two new olefinic carbon signals at $\delta_{\mathrm{C}} 113.7$ and $\delta_{\mathrm{C}}$ 147.2. The protons at $\delta_{\mathrm{H}} 4.65$ and $\delta_{\mathrm{H}} 4.86$ were directly attached to the carbon at $\delta_{\mathrm{C}}$ 113.7. Additional olefinic carbon signals at $\delta_{\mathrm{C}} 127.6$ and $\delta_{\mathrm{C}} 137.2$ were identified as $\mathrm{C}-12$ and $\mathrm{C}-13$, compatible with the substrate. This implied that compound 3
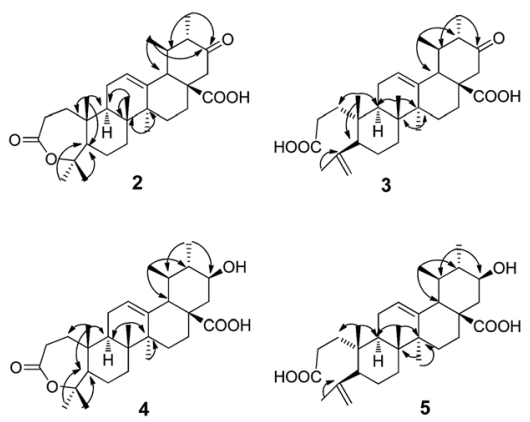

Fig. 2 The key HMBC of compounds $2-5$. could be a product with ring-cleavage. From the HMBC data (Fig. 2 and Appendix 3-5 and 3-6†), HMQC data (Appendix 3-4†) and previous literature, ${ }^{20,21}$ we can conclude that ring-A was cleaved between C-3 and C-4, C-3 was oxygenated to become a carboxyl group and a new double bond was formed between C23 and C-4. Like for metabolite 2, the carbon signal at $\delta_{\mathrm{C}} 209.5$ was a carbonyl group and assigned to C-21 based on the HMBC spectrum. Therefore, product 3 was confirmed as 21-oxo-3,4seco-ursan-4(23),12-dien-3,28-dioic acid.

Metabolite 4 had the molecular formula of $\mathrm{C}_{30} \mathrm{H}_{46} \mathrm{O}_{5}$, as evidenced by the HR-ESI-MS data $\left([\mathrm{M}-\mathrm{H}]^{-}: \mathrm{m} / z\right.$ 485.3263, shown in Appendix 4-1†). According to the ${ }^{1} \mathrm{H}$-NMR spectrum (Appendix 4-2†) and ${ }^{13} \mathrm{C}-\mathrm{NMR}$ spectrum (Appendix 4-3†), the structure of compound $\mathbf{4}$ was similar to that of compound 2 . All of the methyl groups were unchanged compared to those of the substrate. In addition, ring-A also formed a seven-membered ring lactone. The double bond with a chemical shift of $\delta_{\mathrm{C}}$ 126.4 and $\delta_{\mathrm{C}} 137.5$ occurred between $\mathrm{C} 12$ and C13 which was consistent with the substrate. The carbon signal at $\delta_{\mathrm{C}} 71.2$, which correlated with the proton signal at $\delta_{\mathrm{H}} 3.43$, was confirmed to be C-21 from the HMBC data (Fig. 2 and Appendix $4-5 \dagger$ ) whereas C-21 was a carbonyl group in metabolite 2 . Additionally, the orientation of the hydroxyl group at C-21 was deduced as the $\beta$-position from the coupling constants and splitting pattern of $\mathrm{H}-21\left(\delta_{\mathrm{H}} 3.43, \mathrm{td}, J=4.2,10.8 \mathrm{~Hz}\right)$ in the ${ }^{1} \mathrm{H}-$ NMR spectrum which was at its axial $(\alpha)$ position. Ultimately, metabolite 4 was determined as $21 \beta$-hydroxyl-A-homo-3a-oxaurs-12-en-3-one-28-oic acid.

The molecular formula of metabolite $\mathbf{5}$ was determined as $\mathrm{C}_{30} \mathrm{H}_{46} \mathrm{O}_{5}$ from its HR-ESI-MS spectrum ([M-H] $]^{-}$: 485.3215, shown in Appendix 5-1 $\dagger$ ). In the ${ }^{1} \mathrm{H}-\mathrm{NMR}$ spectrum (Appendix 5$2 \uparrow)$, there were proton signals at $\delta_{\mathrm{H}} 4.65$ and $\delta_{\mathrm{H}} 4.84$ which were similar to those of compound 3. Correspondingly, the olefinic carbon signals at $\delta 113.4$ and $\delta 147.1$ in the ${ }^{13} \mathrm{C}$-NMR spectrum (Appendix 5-3†) were also consistent with metabolite 3. It was deduced that metabolite $\mathbf{5}$ was also a product with ring-A cleavage. The new double bond was assigned between C-4 and C-23, identical to compound 3. The two carboxyl groups were attributed to C-3 and C-28, with chemical shifts at $174.7 \mathrm{ppm}$ and $177.4 \mathrm{ppm}$ respectively. Moreover, the secondary hydroxyl group was assigned to C-21, based on the proton signal at $\delta_{\mathrm{H}}$ 3.19 which correlated with the carbon signal at $\delta_{\mathrm{C}} 69.0$ in the HMQC spectrum (Appendix 5-4 $\dagger$ ). The orientation of the $-\mathrm{OH}$ group was determined to be its $\beta$-position from the coupling constants and splitting pattern of $\mathrm{H}-21(\mathrm{td}, J=4.2,10.8 \mathrm{~Hz})$. Based on the above evidence, metabolite 5 was identified as $21 \beta$ hydroxyl-3,4-seco-ursan-4(23),12-dien-3,28-dioic acid.

\section{Anti-HCV activity of UA and biotransformation products}

Evaluation of the anti-HCV activity of UA and its transformation products was achieved in this study for blocking HCV entry. The development of a HCV pseudo-particle (HCVpp) and vesicular stomatitis virus G protein pseudo-particle (VSVG-pp) has made it possible to readily observe HCVpp-mediated cell entry in vitro. Fig. 3A shows the results of the test for HCVpp entry blocking. Concentrations of $1 \mu \mathrm{M}$ and $5 \mu \mathrm{M}$ of the studied compounds 

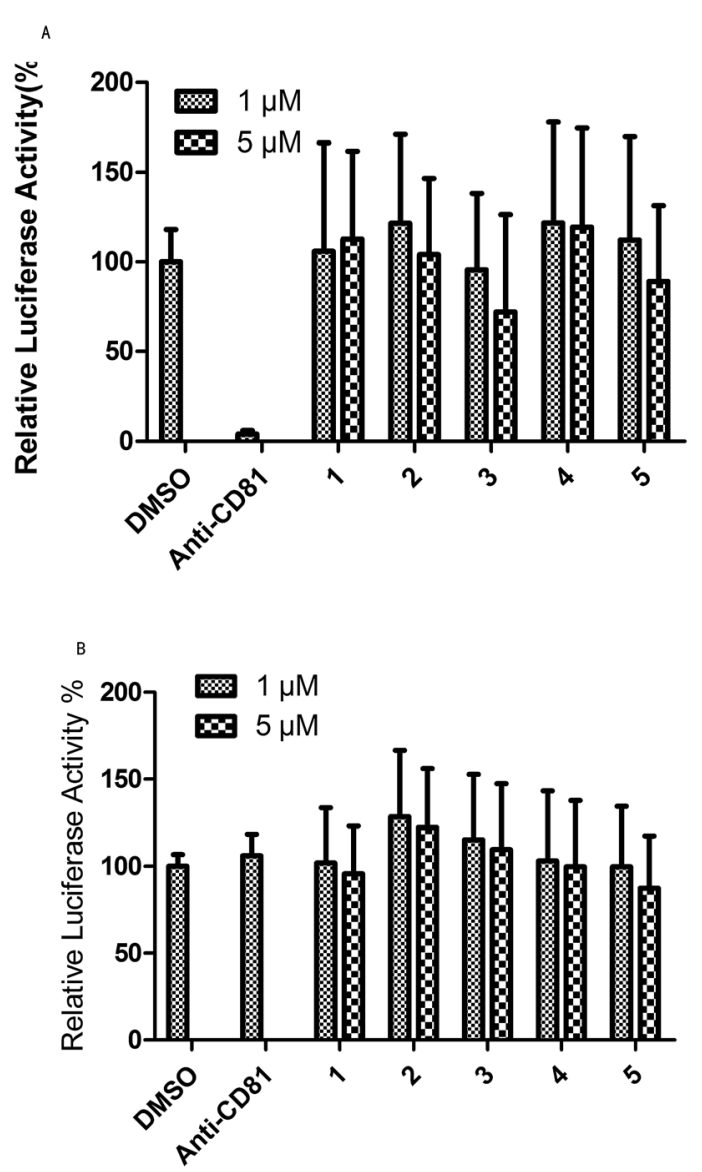

Fig. 3 An anti-HCV activity test based on HCVpp and VSVG-pp entry assay: 1 is the substrate and $2-5$ are products.

and 1\% DMSO, as the solvent control, were evaluated and antiCD81 was used as a positive control which emulated the blocking of HCV entry. From Fig. 3, compound 3 could block HCV entry at $1 \mu \mathrm{M}$ and $5 \mu \mathrm{M}$ while compounds 2 and 5 could block HCV entry at a higher concentration of $5 \mu \mathrm{M}$. Fig. $3 \mathrm{~B}$ shows the results of the test for the VSVG-pp assay that indicated the specificity of HCV entry blocking. The specificity of anti-CD81 was taken as the positive control. Compound 2 showed the best specificity for HCV entry at $1 \mu \mathrm{M}$ and $5 \mu \mathrm{M}$. The specificity for anti-HCV activity of compound $\mathbf{3}$ was slightly higher than that of the control and substrate at both concentrations. Candidates with both high HCV entry blocking activity and high specificity were desirable. Therefore, product 3 showed the best anti-HCV activity among the five compounds at concentrations of $1 \mu \mathrm{M}$ and $5 \mu \mathrm{M}$. Product 2 showed better activity for blocking HCV entry at $5 \mu \mathrm{M}$ (Fig. 3).

\section{Possible transformation pathway of UA by G. roseum CGMCC 3.3657}

Based on the products obtained, the possible transformation pathway of UA by G. roseum CGMCC 3.3657 was proposed as shown in Fig. 4. The substrate 1 was first hydroxylated at C-21 to afford product 4 . Product 4 was then either oxidised at C-21 to afford product 2 or its seven-membered ring was cleaved to form the possible intermediate I. Compound $\mathbf{5}$ was formed from possible intermediate I by the loss of one molecule of water. Compound $\mathbf{3}$ could be formed either from compound $\mathbf{5}$ or from compound 2 through the possible intermediate II as shown in Fig. 4.

\section{Experimental}

\section{General experimental procedure}

Crystallization was performed in $\mathrm{MeOH}$ and petroleum ether/ THF. NMR spectra were recorded on a Bruker DRX-600 spectrometer operating at $600 \mathrm{MHz}$ and $150 \mathrm{MHz}$ in $\mathrm{CDCl}_{3}$ or DMSO- $\mathrm{d}_{6}$ with tetra-methylsilane (TMS) as an internal standard. High-resolution electrospray ionization mass spectra (ESI-MS) were obtained using a Thermo LTQ Orbitrap XL mass spectrometer. Standard pulse sequences were utilized to obtain HMQC and HMBC data. Column chromatography was carried out on silica gel (100-200 mesh and 300-400 mesh, Qingdao Oceanic Chemicals, China). TLC analyses were carried out on pre-coated silica gel GF254 plates $(0.25 \mathrm{~mm}$ thick, Qingdao Oceanic Chemicals, China). Visualization of the TLC plates was performed by using a $10 \% \mathrm{H}_{2} \mathrm{SO}_{4}$ in $95 \%$ ethanol spray reagent, followed by heating. General solvents and reagents were purchased from the Beijing Chemical Industry Company, Beijing, China. The microbes were purchased from the China General Microbiological Culture Collection centre (CGMCC). Optional rotations were recorded on a Perkin-Elmer341 at $509 \mathrm{~nm}$ and $20{ }^{\circ} \mathrm{C}$. The melting point was recorded on the apparatus uncorrected.

\section{Substrate}

The substrate ursolic acid (purity $\geqq 98 \%$ ) was purchased from Changsha Staherb Natural Ingredients Co. Ltd in China. Its structure was characterized by comparison of the ${ }^{1} \mathrm{H}-\mathrm{NMR}$ and ${ }^{13} \mathrm{C}$-NMR spectra measured with those reported in literature. ${ }^{20,22}$

\section{Microorganisms and culture conditions}

The microorganism G. roseum CGMCC 3.3657 was purchased from the China General Microbiological Culture Collection centre (CGMCC). The preliminary screening experiment of $G$. roseum CGMCC 3.3657 was carried out in potato dextrose medium (consisting of $200 \mathrm{~g}$ potato boiled for $20 \mathrm{~min}$; dextrose, $20 \mathrm{~g}$; peptone, $10 \mathrm{~g}$; distilled $\mathrm{H}_{2} \mathrm{O}, 1000 \mathrm{~mL}$ ). Standard two-stage fermentation was applied. The cultures were grown in $100 \mathrm{~mL}$ Erlenmeyer flasks containing $40 \mathrm{~mL}$ of medium. After incubation at $28^{\circ} \mathrm{C}$ and $160 \mathrm{rpm}$ in the shaker for 3 days, the substrate, $0.5 \mathrm{mg}$, (dissolved in ethanol) was added into the flasks for another 20 days and harvested and extracted three times with equal volumes of EtOAc. The extracts were evaporated under reduced pressure on a rotary evaporator $\left(50{ }^{\circ} \mathrm{C}\right)$ and detected by TLC. Two culture controls with only the substrate and only the fungi, respectively, were used simultaneously under the same conditions as above. 


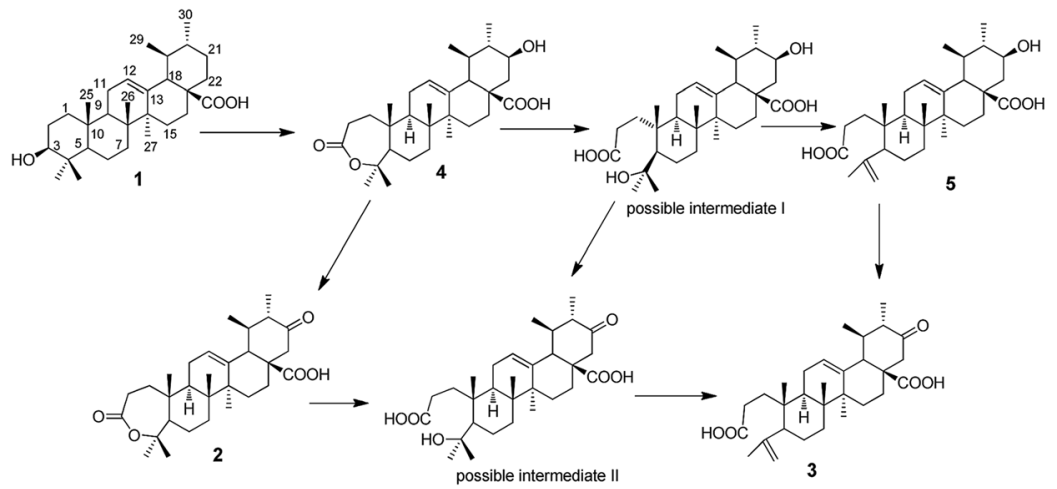

Fig. 4 The possible transformation pathway of UA by G. roseum CGMCC 3.3657.

\section{Biotransformation procedures and isolation of metabolites}

The preparative scale biotransformation of UA by G. roseum CGMCC 3.3657 was carried out in ten $1000 \mathrm{~mL}$ flasks each containing $400 \mathrm{~mL}$ of potato dextrose medium. The cultures were incubated for 72 hours before $400 \mathrm{mg}$ of substrate in total (suspended in ethanol) was evenly added. The conditions and procedures for incubation and extraction were the same as described above. The crude extract, $740 \mathrm{mg}$, was subjected to column chromatography on silica gel (300-400 mesh, $25 \mathrm{~g})$ with stepwise elution using petroleum ether/acetone/acetic acid from $100: 1: 0.1$ to acetone. Four fractions were obtained: fraction A (36 mg), fraction B (38 mg), fraction C (194 mg) and fraction D (70 mg).

Fraction A was further re-crystallized in petroleum ether/THF to afford metabolite $2(25 \mathrm{mg}, 6.25 \%)$. Fraction B was further purified by column chromatography on silica gel (300-400 mesh, $7 \mathrm{~g}$ ) by eluting stepwise with $\mathrm{CHCl}_{3} /$ petroleum ether (85: 35$)$ to afford metabolite 3 ( $4 \mathrm{mg}, 1 \%$ ). Fraction $\mathrm{C}$ was further re-crystallized in methanol to afford metabolite 4 (32 $\mathrm{mg}, 8 \%$ ) and the mother liquor was further purified by column chromatography on silica gel (300-400 mesh, $9.5 \mathrm{~g}$ ) by eluting stepwise with $\mathrm{CHCl}_{3} / \mathrm{MeOH}$ from $100: 2$ to $100: 8$ and with petroleum ether/acetone from $100: 11$ to $11: 13$ to afford metabolite 5 (6 mg, 1.5\%).

Metabolite 2: white crystal, $\operatorname{mp} 263-265{ }^{\circ} \mathrm{C},[\alpha]_{20}^{\mathrm{D}}+54.4^{\circ}(c=$ $1.23 \times 10^{-4}$, EtOH), HR-ESI-MS: $483.3104[\mathrm{M}-\mathrm{H}]^{-}$(calcd 483.3105). For ${ }^{13} \mathrm{C}-\mathrm{NMR}$ ( $150 \mathrm{MHz}$, DMSO-d ${ }_{6}$ ) and ${ }^{1} \mathrm{H}-\mathrm{NMR}(600$ MHz, DMSO-d ${ }_{6}$ ) spectra see Tables 1 and 2.

Metabolite 3: white crystal, mp $217-220{ }^{\circ} \mathrm{C},[\alpha]_{20}^{\mathrm{D}}+27.2^{\circ}(c=$ $8.46 \times 10^{-3}$, EtOH), HR-ESI-MS: $483.3105[\mathrm{M}-\mathrm{H}]^{-}$(calcd 483.3105). For ${ }^{13} \mathrm{C}-\mathrm{NMR}$ (150 $\mathrm{MHz}, \mathrm{CDCl}_{3}$ ) and ${ }^{1} \mathrm{H}-\mathrm{NMR}(600$ $\mathrm{MHz}, \mathrm{CDCl}_{3}$ ) spectra see Tables 1 and 2 .

Metabolite 4: white solid, mp $204-206{ }^{\circ} \mathrm{C},[\alpha]_{20}^{\mathrm{D}}+63.6(c=$ $6.92 \times 10^{-3}$, EtOH), HR-ESI-MS: $485.3263[\mathrm{M}-\mathrm{H}]^{-}$(calcd 485.3262). For ${ }^{13} \mathrm{C}-\mathrm{NMR}\left(150 \mathrm{MHz}, \mathrm{CDCl}_{3}\right.$ ) and ${ }^{1} \mathrm{H}-\mathrm{NMR}(600$ $\mathrm{MHz}, \mathrm{CDCl}_{3}$ ) spectra see Tables 1 and 2.

Metabolite 5: white solid, $\operatorname{mp} 201-203{ }^{\circ} \mathrm{C},[\alpha]_{20}^{\mathrm{D}}+80.4^{\circ}(c=$ $2.07 \times 10^{-4}$, EtOH), HR-ESI-MS: $485.3215[\mathrm{M}-\mathrm{H}]^{-}$(calcd 485.3262). For ${ }^{13} \mathrm{C}-\mathrm{NMR}$ ( $150 \mathrm{MHz}, \mathrm{DMSO}-\mathrm{d}_{6}$ ) and ${ }^{1} \mathrm{H}-\mathrm{NMR}$ (600 $\mathrm{MHz}, \mathrm{DMSO}-\mathrm{d}_{6}$ ) spectra see Tables 1 and 2.

\section{Anti-HCV activity of UA and biotransformation product evaluation}

It was reported that the connection of the virus to the cell surface after viral entry was the first step in a cascade of interactions. Host cell infection is initiated by binding of the virion to cell-surface receptors. Using recombinant $\mathrm{HCV}$ envelope glycoproteins and a HCV-pseudo type particle (HCVpp), several cell surface molecules have been identified as interacting with the HCV during viral binding and entry. Currently, three host

Table $1{ }^{13} \mathrm{C}-\mathrm{NMR}$ data of compounds 2-5 (150 MHz) ${ }^{a}$

\begin{tabular}{|c|c|c|c|c|}
\hline No. & Product 2 & Product 3 & Product 4 & Product 5 \\
\hline 1 & 37.8 & 34.1 & 38.3 & 33.9 \\
\hline 2 & 31.7 & 28.5 & 32.1 & 28.2 \\
\hline 3 & 174.2 & 178.5 & 175.2 & 174.1 \\
\hline 4 & 85.4 & 147.1 & 86.2 & 147.1 \\
\hline 5 & 53.4 & 51.0 & 54.7 & 49.3 \\
\hline 6 & 25.1 & 24.5 & 23.7 & 24.0 \\
\hline 7 & 31.7 & 31.8 & 32.4 & 31.3 \\
\hline 8 & 39.1 & 39.6 & 39.6 & 38.7 \\
\hline 9 & 46.5 & 38.2 & 47.4 & 37.1 \\
\hline 10 & 39.2 & 39.5 & 39.8 & 38.7 \\
\hline 11 & 23.3 & 24.0 & 25.2 & 23.0 \\
\hline 12 & 126.0 & 127.6 & 126.4 & 124.8 \\
\hline 13 & 137.2 & 137.1 & 137.5 & 138.1 \\
\hline 14 & 41.6 & 42.5 & 42.2 & 42.1 \\
\hline 15 & 27.4 & 28.1 & 28.0 & 27.6 \\
\hline 16 & 25.6 & 26.0 & 22.9 & 24.8 \\
\hline 17 & 50.1 & 51.4 & 48.7 & 47.8 \\
\hline 18 & 51.7 & 52.7 & 52.2 & 52.2 \\
\hline 19 & 40.6 & 41.8 & 38.0 & 37.5 \\
\hline 20 & 50.1 & 51.3 & 46.6 & 46.4 \\
\hline 21 & 209.5 & 209.5 & 71.2 & 69.0 \\
\hline 22 & 49.8 & 50.7 & 44.6 & 45.2 \\
\hline 23 & 31.8 & 113.7 & 32.4 & 113.4 \\
\hline 24 & 30.4 & 23.6 & 25.8 & 23.5 \\
\hline 25 & 16.8 & 19.5 & 17.1 & 19.3 \\
\hline 26 & 16.6 & 17.3 & 16.9 & 17.0 \\
\hline 27 & 23.2 & 23.9 & 23.3 & 23.0 \\
\hline 28 & 175.7 & 179.5 & 179.6 & 177.4 \\
\hline 29 & 18.1 & 18.7 & 17.1 & 17.3 \\
\hline 30 & 12.5 & 12.6 & 15.6 & 15.8 \\
\hline
\end{tabular}

${ }^{a}$ Solvent DMSO- $\mathrm{d}_{6}$ was used for products 2 and $\mathbf{5}$; solvent $\mathrm{CDCl}_{3}$ was used for products 3 and 4. 
Table 2 The characteristic ${ }^{1} \mathrm{H}-\mathrm{NMR}$ data of compounds $2-5(600 \mathrm{MHz})^{a}$

\begin{tabular}{|c|c|c|c|c|}
\hline No. & Product 2 & Product 3 & Product 4 & Product 5 \\
\hline 1 & $1.61(\mathrm{o}), 1.49(\mathrm{o})$ & $1.61(\mathrm{~m}), 1.58(\mathrm{~m})$ & $1.56(\mathrm{~m}), 1.79(\mathrm{~m})$ & $1.45(\mathrm{~m})$ \\
\hline 2 & $2.58(\mathrm{o})$ & $2.39(\mathrm{~m}), 2.56(\mathrm{~m})$ & $2.61(\mathrm{~m})$ & $2.05(\mathrm{~m})$ \\
\hline 4 & - & - & - & - \\
\hline 5 & $1.68(\mathrm{o})$ & $1.92(0)$ & $1.66(\mathrm{~d}, 10.8)$ & $1.96(\mathrm{dd}, 1.8,12.6)$ \\
\hline 6 & $1.76(\mathrm{~m})$ & $1.37(\mathrm{~m})$ & $1.99(\mathrm{~m})$ & $1.30(\mathrm{~m})$ \\
\hline 9 & $1.61(\mathrm{o})$ & $1.68(\mathrm{~m})$ & $1.62(\mathrm{~m})$ & $1.86(\mathrm{~m})$ \\
\hline 10 & - & - & - & - \\
\hline 11 & $1.94(\mathrm{o})$ & $1.93(\mathrm{~m})$ & $1.85(\mathrm{~m})$ & $1.04(\mathrm{o})$ \\
\hline 12 & $5.32(\mathrm{t}, 3.6)$ & $5.40(t, 3.6)$ & $5.32(\mathrm{t}$-like $)$ & $5.16(t, 3.6)$ \\
\hline 13 & - & - & - & - \\
\hline 14 & - & - & - & - \\
\hline 19 & $1.69(\mathrm{o})$ & $1.77(\mathrm{~m})$ & $1.44(\mathrm{~m})$ & $1.40(\mathrm{~m})$ \\
\hline 20 & $2.23(\mathrm{dd}, 6.0,10.8)$ & $2.14(\mathrm{dd}, 6.0,10.8)$ & $0.98(\mathrm{o})$ & $0.79(\mathrm{~m})$ \\
\hline 21 & - & - & $3.43(\mathrm{td}, 4.2,10.8)$ & $3.19(\mathrm{td}, 4.2,10.8)$ \\
\hline 22 & $2.14(\mathrm{~d}, 13.2), 2.69(\mathrm{~d}, 12.6)$ & $2.65(\mathrm{~d}, 12.6), 2.39(\mathrm{~d}, 12.6)$ & $1.57(\mathrm{~m}), 2.41(\mathrm{dd}, 4.2,12.6)$ & $1.80(\mathrm{~m}), 1.35(\mathrm{~m})$ \\
\hline 23 & $1.40(\mathrm{~s})$ & $4.86(\mathrm{brs}), 4.65$ (brs) & $1.48(\mathrm{~s})$ & 4.65 (brs), 4.84 (brs) \\
\hline 24 & $1.34(\mathrm{~s})$ & $1.72(\mathrm{~s})$ & $1.42(\mathrm{~s})$ & $1.71(\mathrm{~s})$ \\
\hline 25 & $1.08(\mathrm{~s})$ & $0.92(\mathrm{~s})$ & $1.15(\mathrm{~s})$ & $0.86(\mathrm{~s})$ \\
\hline 26 & $0.81(\mathrm{~s})$ & $0.82(\mathrm{~s})$ & $0.84(\mathrm{~s})$ & $0.80(\mathrm{~s})$ \\
\hline 27 & $1.02(\mathrm{~s})$ & $1.05(\mathrm{o})$ & $1.07(\mathrm{~s})$ & $1.05(\mathrm{~s})$ \\
\hline 28 & - & - & - & - \\
\hline 29 & $0.96(d, 6.6)$ & $1.01(\mathrm{~d}, 6.6)$ & $0.91(\mathrm{~d}, 6.0)$ & $0.84(\mathrm{~d}, 6.6)$ \\
\hline 30 & $0.93(\mathrm{~d}, 6.6)$ & $1.05(\mathrm{~d}, 6.6)$ & $1.08(\mathrm{~d}, 6.0)$ & $0.98(\mathrm{~d}, 6.6)$ \\
\hline
\end{tabular}

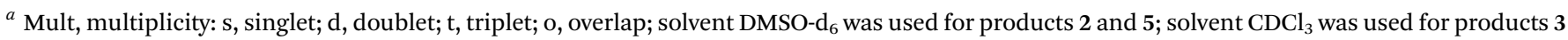
and 4.

proteins, CD81, SR-BI and claudin-1 (CLDN1), are thought to be essential (co-)receptors for HCV entry. CD81 was regarded as the best studied of the HCV (co-)receptors. At present, treatments for $\mathrm{HCV}$ infection are limited and vaccines to prevent $\mathrm{HCV}$ infection are not available. Studying interactions with $\mathrm{HCV}$ entry seems to be a promising approach for drug design and screening. The anti-HCV activity was evaluated by the method described by Hengli Tang. ${ }^{23}$ The substrate and transformation products were tested for their capacity to block HCV entry by (HCVpp) entry assay. The specificity of anti-HCV entry was evaluated by using a vesicular stomatitis virus $\mathrm{G}$ protein pseudoparticle (VSV G-pp).

\section{Conclusions}

In recent years, the idea of "returning to nature" has made researchers begin to look back to natural medicine. Natural products are structurally and biologically interesting compounds. Isolated natural compounds are often available in minute amounts. Thus, the synthesis of natural products also provides a powerful means to solve supply problems in clinical trials and market the products in bulk amounts. Biotransformation was regarded as an alternative to produce new compounds. In this paper it is reported that four new products from UA were afforded by microbial transformation. A BaeyerVilliger oxidative reaction occurred which was catalyzed by $G$. roseum CGMCC 3.3657. A transformation pathway was proposed. Moreover, the anti-HCV activity of UA and the derived products was tested. Compounds 2 and $\mathbf{3}$ showed a small improvement in activity compared to the substrate. The results reported in this article will help future researchers for further investigation.

\section{Conflicts of interest}

There are no conflicts to declare.

\section{Acknowledgements}

This work is supported by the National Nature Science Foundation of China (Project No. 21462057 and 21172267) and funds from the Guizhou Science and Technology Department (QKHLH-2014-7555).

\section{References}

1 G.-T. Chen, M. Yang, Y. Song, Z.-Q. Lu, J.-Q. Zhang, H.-L. Huang, L.-J. Wu and D.-A. Guo, Appl. Microbiol. Biotechnol., 2008, 77, 1345-1350. 
2 M. Ahmad, W. Ahmad, M. Ahmad, M. Zeeshan, Obaidullah, M. Nisar and F. Shaheen, J. Enzyme Inhib. Med. Chem., 2008, 23, 1023-1027.

3 F.-Q. Wang, B. Li, W. Wang, C.-G. Zhang and D.-Z. Wei, Appl. Microbiol. Biotechnol., 2007, 77, 771-777.

4 S. Fontanay, M. Grare, J. Mayer, C. Finance and R. E. Duval, J. Ethnopharmacol., 2008, 120, 272-276.

5 M. Jamal, S. S. Imam, M. Aqil, M. Amir, S. R. Mir and M. Mujeeb, Int. Immunopharmacol., 2015, 29, 361-369.

6 A. R. S. Colla, J. M. Rosa, M. P. Cunha and A. L. S. Rodrigues, Eur. J. Pharmacol., 2015, 758, 171-176.

7 F. Meng, H. Ning, Z. Sun, F. Huang, Y. Li, X. Chu, H. Lu, C. Sun and S. Li, J. Funct. Foods, 2015, 17, 172-182.

8 S.-M. Jang, S.-T. Yee, J. Choi, M.-S. Choi, G.-M. Do, S.-M. Jeon, J. Yeo, M.-J. Kim, K.-I. Seo and M.-K. Lee, Int. Immunopharmacol., 2009, 9, 113-119.

9 Z. Feng, C. Wu, J. Zhou, F. Wu, J. Li, T. Li and Y. Yin, J. Funct. Foods, 2015, 14, 456-468.

10 Y. Wang, J. Song, S. F. Chow, A. H. L. Chow and Y. Zheng, Int. J. Pharm., 2015, 494, 479-489.

11 Z.-Q. Ge, X.-Y. Du, X.-N. Huang and B. Qiao, J. Drug Delivery Sci. Technol., 2015, 29, 210-217.

12 S. Rashid, B. A. Dar, R. Majeed, A. Hamid and B. A. Bhat, Eur. J. Med. Chem., 2013, 66, 238-245.

13 S.-B. Fu, J.-S. Yang, J.-L. Cui and D.-A. Sun, Fitoterapia, 2013, 86, 123-128.
14 S.-B. Fu, J.-S. Yang, J.-l. Cui, Q.-f. Meng, X. Feng and D.-A. Sun, Fitoterapia, 2011, 82, 1057-1061.

15 S. H. Xu, C. Zhang, W. W. Wang, B. Y. Yu and J. Zhang, RSC Adv. , 2017, 7, 20754-20759.

16 J. R. R. Pinho and F. D. M. Malta, Hepatitis Virus Scientific Background: Epidemiology and Mechanism of Carcinogenesis of Hepatitis C Virus (HCV), Springer International Publishing, 2015.

17 H. Wang, Q. Wang, S.-L. Xiao, F. Yu, M. Ye, Y.-X. Zheng, C.-K. Zhao, D.-A. Sun, L.-H. Zhang and D.-M. Zhou, Eur. J. Med. Chem., 2013, 64, 160-168.

18 H. Wang, F. Yu, Y. Peng, Q. Wang, X. Han, R.-Y. Xu, X.-S. Zhou, C.-X. Wan, Z.-B. Fan, P.-X. Jiao, Y.-M. Zhang, L.-H. Zhang, D.-M. Zhou and S.-L. Xiao, Eur. J. Med. Chem., 2015, 102, 594-599.

19 L.-K. Meng, Q. Wang, T. Tang, S.-L. Xiao, L.-H. Zhang, D.-M. Zhou and F. Yu, Chin. J. Chem., 2017, 8, 1322-1328.

20 N. Shirane, Y. Hashimoto, K. Ueda, H. Takenaka and K. Katoh, Phytochemistry, 1996, 43, 99-104.

21 H.-Y. Tu, A.-M. Huang, B.-L. Wei, K.-H. Gan, T.-C. Hour, S.-C. Yang, Y.-S. Pu and C.-N. Lin, Bioorg. Med. Chem., 2009, 17, 7265-7274.

22 C. Chun-Te, W. Tzong-Der, T. Shang-Jie and L. Jen-Kun, FEBS Lett., 2007, 581, 5735-5742.

23 H. Tang, Hepatitis C: Methods and Protocols, Humana Press, FL USA, 2nd edn, 2008. 